\title{
ANALISIS PENETAPAN NILAI PENGGANTI WAJAR DALAM PENGADAAN TANAH UNTUK KEPENTINGAN UMUM DI KOTA LHOKSEUMAWE (STUDI KASUS PEMBUATAN JALUR REL KERETA API DI KECAMATANMUARA DUA KOTA LHOKSEUMAWE) \\ Dulmuzid, ${ }^{1}$ Sukaria Sinulingga ${ }^{2}$, Sugiharto Pujangkoro ${ }^{3}$ \\ Universitas Sumatera Utara
}

\begin{abstract}
Determination of fair replacement value in land acquisition for public interest in Lhokseumawe City is carried out by the appraisal team with due regard to physical values and non-physical values in accordance with Law No. 2 of 2012 and Indonesian Assessment Standards. The obstacles in implementing compensation for land acquisition for the construction of the Lhokseumawe City railroad are barriers originating from communities holding rights to land, buildings and plants as well as objects related to land are a lack of public awareness to participate in development and lack of understanding of the meaning of public interest, social function of land rights.
\end{abstract}

Keywords : Land Acquisition, Land Assessment, Fair Replacement Value

Correspondence to : dul.evi.07@gmail.com

\begin{abstract}
ABSTRAK
Penetapan nilai pengganti wajar dalam pembebasan tanah untuk kepentingan umum di Kota Lhokseumawe dilakukan oleh tim appraisal dengan memperhatikan nilai fisik dan nilai non fisik sesuai dengan UU No 2 tathun 2012 dan Standar Penilaian Indonesia. Hambatan-hambatan dalam pelaksanaan pemberian ganti kerugian dalam pengadaan tanah untuk pembangunan rel kereta api Kota Lhokseumawe adalah hambatan yang berasal dari masyarakat pemegang hak atas tanah, bangunan dan tanaman serta benda-benda yang berkaitan dengan tanah adalah kurangnya kesadaran masyarakat untuk berperan serta dalam pembangunan dan kurang pemahaman terhadap arti kepentingan umum, fungsi sosial hak atas tanah.
\end{abstract}

Kata kunci $\quad$ : Pembebasan Tanah, Penilaian Tanah, Nilai Pengganti Wajar Korespondensi : dul.evi.07@gmail.com

\section{PENDAHULUAN}

Pembangunan suatu wilayah di Indonesia saat ini dilatarbelakangi terbatasnya ketersediaan dan daya tampung tanah untuk pembangunan yang diakibatkan oleh pertumbuhan dan distribusi penduduk. Disamping semakin meningkatnya kegiatan kehidupan sosial ekonomi masyarakat wilayah yang tercermin dalam bentuk perluasan ruang wilayah meningkat pula. Untuk itu, ketersediaan dan daya tampung tanah serta jumlah dan distribusi penduduk kota 
menjadi aspek-aspek yang sangat penting dan mutlak untuk diperhatikan dalam perencanaan dan pengembangan sebuah wilayah. (Asbi Samli, 2012).

Perkembangan penduduk perkotaan yang cukup pesat diikuti oleh perkembangan jenis dan intensitas kegiatan dengan segala fasilitasnya juga berpengaruh dalam merubah wujud fisik kota dengan cepat. Demikian pula dengan tuntutan kegiatan dan pengadaan prasarana dan fasilitas wilayah yang melampaui daya dukung tanah serta tidak menghiraukan kesesuaian tanahnya, maka timbul problem lingkungan. Permasatanah seperti ini akan terus berlangsung sedikit demi sedikit dan suatu saat akan sulit atau mahal untuk diselesaikan akibat keterlambatan dalam pengendaliannya.

Pada tahun 2015 yang lalu pemerintah melalui Kasubbag Otonomi Daerah pada Bagian Pemerintahan Kota Lhokseumawe merencanakan pembangunan kereta api di Lhokseumawe dengan panjang 18.9 kilometer. Dimana relnya membentang dari Desa Paloh Meuria Kecamatan Muara Satu hingga Desa Blang Punteut Kecamatan Blang Mangat. Lokasi ini merupakan jalur Kereta Api baru lintas Sumatera Bagian Utara sudah menjadi prioritas nasional dalam mengurai kemacetan transportasi darat, untuk itu sangat perlu dilakukan percepatan. Jaringan KA di Sumatera Utara ini belum tersambung/terintegrasi dengan jaringan KA yang ada di Aceh. Pembangunan Trans Sumatera Railway sebagaimana hasil dari Forum Gubernur Se Sumatera, akan menghubungkan setiap provinsi di pulau Sumatera dengan jalur KA. Pembangunan Jalur KA Trans Sumatera sebagai backbone perpindahan arus barang maupun orang di pulau Sumatera yang akan meningkatkan perekonomian di pulau Sumatera.

Kota Lhokseumawe merupakan kota yang memiliki potensi yang sangat bagus secara bisnis dan pembangunan. Salah satu kota yang berada di Provinsi Aceh. Kota Lhokseumawe ditetapkan statusnya dikota berdasarkan UndangUndang Nomor 2 Tahun 2001 yang wilayahnya mencakup 4 Kecamatan yaitu: Banda Sakti, Blang Mangat, Muara Dua dan Muara Satu. Kota Lhokseumawe memiliki luas $212 \mathrm{~km}$ dengan jumlah penduduk pada tahun 2010 adalah188.974 jiwa. Penggunaan tanah terbesar di Kota Lhokseumawe adalah untuk pemukiman seluas $9.490 \mathrm{Ha}$ atau sekitar 52,1\% dari luas yang ada. Kebutuhan tanah yang menonjol adalah untuk usaha kebun campuran $4.59 \mathrm{Ha}$ atau sekitar 25,35\%, disamping untuk kebutuhan persawahan seluas $1.679 \mathrm{Ha}$ atau sekitar 9,27\% untuk kebutuhan perkebunan rakyat telah dimanfaatkan seluas $674 \mathrm{Ha}$ atau sekitar 3,72\% dan untuk lain-lainnya

Namun, dalam mewujudkan pembangunan rel kereta api di Kecamatan Muara Dua Kota Lhokseumawe tidaklah mudah karena harus melalui proses pembebasan tanah. Pengadaan tanah bagi pelaksanaan pembangunan untuk kepentingan umum oleh Pemerintah Kota Lhokseumawe dilaksanakan dengan cara pelepasan/penyerahan hak atas tanah. Sedangkan pengadaan tanah selain bagi pelaksanaan pembangunan untuk kepentingan umum oleh Pemerintah dilakukan dengan cara jual beli, tukar menukar atau cara lain yang disepakati secara sukarela oleh pihak-pihak yang bersangkutan. Pelepasan/penyerahan hak atas tanah tersebut dilakukan berdasarkan prinsip kehormatan terhadap hak atas tanah yaitu pemberian ganti rugi. Pasal 5 Perpres nomor 65 tahun 2006, tentang perubahan atas Perpres nomor 36 tahun 2005, tentang pengadaan tanah bagi pelaksanaan pembangunan untuk kepentingan umum, merupakan pembangunan untuk kepentingan umum. 
ini secara tegas membagi bentuk-bentuk pembangunan untuk kepentingan umum.

Adapun bentuk-bentuknya, antara lain: jalan umum dan jalan tol, rel kereta api, saluran air, saluran pembuangan air dan sanitasi, waduk, bendungan, irigasi dan bangunan pengairan lainnya, pelabuhan, bandar udara, stasiun kereta api, terminal, fasilitas kesehatan umum, seperti tanggul, tempat pembuangan sampah, pembangkit dan transmisi tenaga listrik. Bagi pelaksanaan pembangunan untuk kepentingan umum dilaksanakan dengan cara pelepasan atau penyerahan hak atas tanah melalui panitia pengadaan tanah untuk tanah yang lebih dari satu hektar. Pengadaan tanah sebagai suatu perbuatan hukum yang dilakukan pemerintah untuk mendapatkan tanah bagi kepentingan tertentu dengan cara memberikan ganti kerugian kepada si empunya (baik perorangan atau badan hukum) tanah menurut tata cara dan besaran nominal tertentu.( Baihaqi,2014)

Rasionalitasnya, hampir semua kajian pada literatur tentang aspek hukum pengadaan tanah,pemerintah atas nama Negara memerlukan tanah (Chang, Y.C., 2012) namun, keterbatasan ketersediaan tanah untuk pembangunan pengadaan tanah terhadap tanah yang dikuasai oleh Negara (Pasal 2, 6, dan 18 UU No.5 Tahun 1960 (UUPA) tidak mencukupi luasnya. kepentingan umum adalah kepentingan orang banyak yang untuk mengaksesnya tidak mensyaratkan beban tertentu. Misalnya kepentingan umum pembangunan jalan raya yang setiap orang bisa melewatinya tanpa harus membayar, yang harus dibedakan dengan bila masuk hotel yang wajib bayar.

Dengan kata lain, tanah merupakan modal dasar pembangunan rel kereta api di Kecamatan Muara Dua Kota Lhokseumawe. Kegiatan pembangunan yang dilaksanakan di segala bidang kehidupan baik untuk kepentingan umum maupun kepentingan swasta selalu membutuhkan tanah sebagai wadah untuk diletakkan dalam pembangunan itu. Perpres Nomor 65 Tahun 2006 memberikan penegasan yaitu pembatasan pengadaan tanah untuk kepentingan umum yang hanya terbatas pada kepentingan umum yang dilaksanakan oleh Pemerintah atau Pemerintah Daerah yang selanjutnya dimiliki oleh Pemerintah atau Pemerintah Daerah.

Perpres Nomor 65 Tahun 2006 tersebut, tidak lagi melalui mekanisme pencabutan hak atas tanah. Artinya pemerintah memberikan perlindungan kepada masyarakat untuk tidak mengambil alih hak tanahnya secara paksa melainkan melalui mekanisme pelepasan atau penyerahan hak atas tanah yang dilakukan melalui musyawarah dan kesepakatan para pihak yang berkepentingan. Sehingga, dimungkinkan pengadaan tanah bagi pelaksanaan pembangunan untuk kepentingan umum.( Baihaq,2014))

Lebih lanjut, luas tanah masyarakat yang akan dibebaskan untuk pembangunan jalur kereta api di Kota Lhokseumawe secara keseluruhan 756 ha. Adapun anggaran untuk pembebasan tanah berasal dari daftar isian pelaksanaan anggaran (DIPA) Balai Teknik Perkeretaapian Wilayah Sumatera Bagian utara Sekarang sudah memasuki tahap pelaksanaan pembebasan tanah masyarakat yang terkena pembangunan rel kereta api yang terencana target penyelesaian secara optimal pada tahun 2025.

Pembangunan jalur Kereta Api Kecamatan Muara Dua Kota Lhokseumawe secara keseluruhan 756 ha. Tentunya sebagai tindak lanjut dari pasal UUPA maka pad tanggal 26 September telah ditetapkan Undang-undang No. 20 tahun 1961 tentang Pencabutan Hak-hak atas tanah dan benda-benda yang berada diatasnya dan Peraturan pemerintah No. 
39 tentang Acara Penetapan Ganti Kerugian Oleh Pengadilan Tinggi. Adanya peraturan tentang pencabutan hak atas tanah tersebut sebenarnya mempunyai dua fungsi, disatu pihak merupakan suatu landasan hukum bagi pihak penguasa untuk memperoleh tanah-tanah penduduk yang diperlukan untuk penyelenggaraan kepentingan umum dan kepentingan pembangunan, sedangkan dipihak lain merupakan suatu jaminan bagi warga masyarkat mengenai hak-haknya atas tanah dari tindakan sewenang-wenang parapenguasa.

Sedang yang dimaksud dengan pencabutan hak adalah pengambilan tanah kepunyaan penduduk oleh negara secarapaksa, yang mengakibatkan hak atas tanah menjadi hapus dan berpindah dari pihak terhadap siapa pencabutan dilakukan kepada pihak yang meminta pencabutan, hal itu tanpa yang bersangkutan melakukan suatu penyelenggaraan atau lalai dalam melakukankewajiban hukumnya dalam Pelaksanaan Pengadaan Tanah dan Proses Pemberian ganti kerugiannya Kereta Api Kota Lhokseumawe.

\section{KAJIAN PUSTAKA}

\section{PengadaAn Tanah}

Istilah "pengadaan tanah" secara yuridis pertama kali dikenal sejak keluarnya Keputusan Presiden (Keppres) No.55 Tahun 1993 tentang Pengadaan Tanah bagi Pelaksanaan Pembangunan untuk Kepentingan Umum. Pengadaan tanah adalah setiap kegiatan untuk mendapatkan tanah dengan cara memberikan ganti kerugian kepada yang berhak atas tanah tersebut. Dalam Peraturan Presiden No. 36 Tahun 2005 sebagai pengganti Keppres diatas, disebutkan bahwa pengadaan tanah adalah setiap kegiatan untuk mendapatkan tanah dengan cara memberikan ganti rugi kepada yang melepaskan atau menyerahkan tanah, bangunan, tanaman, dan benda-benda yang berkaitan dengan tanah atau dengan pencabutan hak atas tanah.24 Kemudian Perpres No. 65 Tahun 2006 mengubah lagi pengertian pengadaan tanah setiap kegiatan untuk mendapatkan tanah dengan cara memberi ganti rugi kepada yang melepaskan atau menyerahkan tanah, bangunan, tanaman, dan benda-benda yang berkaitan dengan tanah.

Terakhir Pasal 1 angka 2 UU No. 2 Tahun 2012 tentang Pengadaan Tanah bagi Pembangunan untuk Kepentingan Umum menyatakan bahwa pengadaan tanah adalah kegiatan menyediakan tanah dengan cara memberi ganti kerugian yang layak dan adil kepada pihak yang berhak. Pihak yang berhak adalah pihak yang menguasai atau memiliki obyek pengadaan tanah. Obyek pengadaan tanah adalah tanah, ruang atas tanah dan bawah tanah, bangunan dan tanaman, benda yang berkaitan dengan tanah, atau lainnya yang dapat dinilai.

Pengertian pengadaan tanah selanjutnya dijabarkan dalam Peraturan Presiden Nomor 71 Tahun 2012 tentang Penyelenggaraan Pengadaan Tanah Untuk Kepentingan Umum dan Peraturan Kepala Badan Pertanahan Nasional Nomor 5 Tahun 2012 tentang Petunjuk Teknis Pelaksanaan Pengadaan Tanah.Dengan demikian dapat disimpulkan bahwa, pengadaan tanah adalah kegiatan pelepasan hak atas tanah dengan memberikan ganti-rugi yang pemanfaatannya harus untuk kepentingan umum. Menurut Undang-Undang No.2 tahun 2012 tentang penyelenggaraan pengadaan tanah bagi pembangunan untuk kepentingan umum, pengadaan tanah adalah kegiatan menyediakan tanah dengan cara memberi ganti kerugian yang layak dan adil kepada pihak yang berhak.

\section{Tata Guna Tanah}

Von Thunen adalah seorang yang 
berkebangsaan Jerman, telah mengusahakan tanah pertaniannya selama 40 tahun. Berdasarkan pengalamannya dia mengemukan satu model atau teori tentang letak tataguna tanah pertanian. Model tersebut menunjukkan adanya perbedaan tentang tataguna tanah dengan bertambahnya jarak dari pasar. Ada dua hal yang dikemukan oleh Von Thunen yaitu:

1. Produktivitas suatu jenis tanaman akan berkurang atau menurun dengan bertambahnya jarak dari pasar. Produktivitas diukur dari segi input pertanian, termasuk banyaknya tenaga buruh, modal, alat bajak, benih dan sebagainya yang digunakan bagi setiap bidang tanah.( Adi, W., 2013)

2. Jenis penggunaan tanah akan berbeda dengan bertambahnya jarak dari pasar. Von Thunen untuk menguji teorinya mengajukan beberapa hipotesis. Adapun hipotesis yang digunakan Von Thunen adalah sebagai berikut:

a. Ada sebuah negara terpencil yang hanya mempunyai sebuah pusat pasaran yang letaknya di tengahtengah.

b. Pusat pasaran tersebut hanya merupakan satu-satunya untuk memasarkan hasil pertanian di negara tersebut. Produksi pertanian hanya merupakan satu-satunya untuk memenuhi kebutuhan aktivitas kota tersebut. Semua petani akan menerima harga penjualan sama dengan di pusat pasaran.

c. Wilayah di seluruh nagara itu adalah seragam dari segi kesuburan, iklim, topografi dan keadaan fisik lainnya. Setiap petani berusaha untuk memaksimumkan keuntungan dari aktivitas pertaniannya.

d. Transportasi ke kota hanya dengan kereta kuda atau berjalan kaki saja.6. Biaya transportasi hanya ditentukan oleh jauhnya jarak perjalanan. e. Tidak ada hubungan dengan penduduk di luar nagara itu dan nagara tersebut adalah tertutup dan mampu memenuhi keperluannya sendiri.

Untuk menentukan nilai tanah Von Thunen menggunakan sewa tanah dari lokasi dimana tanah berada. Von Thunen melihat berbagai tanaman yang dihasilkan oleh daerah-daerah subur dekat pusat pasaran dan ditemukan sewa tanahnya lebih tinggi dari daerah yang jauh dari pusat pasaran. Menurutnya sewa tanah berkaitan dengan perlunya biaya transportasi dari daerah yang jauh ke pusat pasaran Menurut Von Thunen zona yang paling dekat kota pasaran mengusahakan market gardening, berupa sayuran terutama kentang dan susu, karena dalam zona ini ada hasil perahan.

\section{Nilai Pengganti Wajar}

Menurut Harjanto dan Hidayat (2014) Nilai adalah apa yang sepatutnya dibayar oleh seseorang pembeli atau diterima oleh penjual dalam sebuah transaksi. Dalam peneilitian ini bawa nilai yang dimaksud adalah nilai penggantian atas sebuah tanah untuk kepentingan umum, yang yang dimaksud adalah tanah kosong atau tanah yang sudah berdiri bangunan.

Menurut Yusuf (2016) Nilai adalah suatu opini dari manfaat ekonomi atas kepemilikan asset, atau harga yang paling mungkin dibayarkan untuk suatu asset, atau harga yang paling mungkin dibayarkan untuk suatu asset dalam pertukaran, sehingga nilai bukan merupakan fakta.

Istilah nilai pengganti wajar dapat diartikan sebagai berikut " nilai untuk kepentingan pemilik, yang didasarkan kepada kesetaraan dengan nilai pasar atas suatu properti, dengan memperhatikan unsur luar biasa berupa kerugian non fisik yang diakibatkan adanya pengambilalihan hak atas properti. (SPI 2015).

Penilaian untuk keperluan ganti rugi 
meliputi :

1. Ganti kerugian fisik (material) tanah dan/atau bangunan dan/atau tanaman dan/atau benda-benda lain yang berkaitan dengan tanah.

2. Ganti kerugian non fisik (immaterial) terdiri dari penggantian terhadap kerugian pelepasan hak dari pemilik tanah yang akan diberikan dalam bentuk uang (premium), serta kerugian lainnya yang dapat dihitung meliputi biaya transaksi, bunga (kompensasi masa tunggu), kerugian sisa tanah, dan jenis kerugian lainnya yang dinyatakan oleh pemberi tugas dalam surat perjanjian kerja. (SPI 306-1.6)

Dalam Perpres No.71 tahun 2012 pasal 121, telah diatur adanya kebutuhan pengadaan tanah untuk skala kecil. Dalam rangka efisiensi dan efektivitas, pengadaan tanah untuk kepentingan umum yang luasnya tidak lebih dari 1 (satu) hektar, dapat langsung oleh instansi yang memerlukan tanah dengan pemegang hak atas tanah, dengan cara jual beli atau tukar menukar, atau cara lain yang disepakati oleh kedua belah pihak. Kemudian diubah Perpres No. 148 tahun 2015 yaitu :

1. Dalam rangka efisiensi dan efektivitas, pengadaan tanah untuk kepentingan umum yang luasnya tidak lebih dari 5 (lima) hektar, dapat dilakukan langsung oleh instansi yang memerlukan tanah dengan pihak yang berhak.

2. Pengadaan tanah untuk kepentingan umum yang luasnya tidak lebih dari 5 (lima) hektar sebagai mana dimaksud pada ayat 1 (satu) harus sesuai dengan tata cara ruang wilayah.

3. Pengadaan tanah untuk kepentingan umum sebagaimana dimaksud pada ayat 1 (satu) tidak memerlukan penetapan lokasi.

4. Penilaian tanah dalam rangka pengadaan tanah sebagaimana dimaksud pada ayat 1 (satu), instansi yang memerlukan tanah menggunakan hasil penilaian jasa penilaian. Undang - Undang Nomor 2 Tahun 2012 tentang Pengadaan Tanah Bagi Pembangunan Untuk Kepentingan Umum . Dalam Undang - Undang ini yang dimaksud dengan :

1. Instansi adalah Lembaga Negara, Kementerian dan Lembaga Pemerintah nonkementerian, Pemerintah Provinsi, Pemerintah Kabupaten/Kota, dan Badan Hukum Milik Negara/Badan Usaha Milik Negara yang mendapat penugasan khusus Pemerintah.

2. Pengadaan Tanah adalah kegiatan menyediakan tanah dengan cara memberi ganti kerugian yang layak dan adil kepada pihak yang berhak.

3. Pihak yang berhak adalah pihak yang menguasai atau memiliki obyek pengadaan tanah.

4. Objek Pengadaan Tanah adalah tanah, ruang atas tanah dan bawah tanah, bangunan, tanaman, benda yang berkaitan dengan tanah, atau lainnya yang dapat dinilai.

5. Hak atas Tanah adalah hak atas tanah sebagaimana dimaksud dalam Undang - Undang Nomor 5 Tahun 1960 tentang Peraturan Dasar Pokok pokok Agraria dan hak lain yang akan ditetapkan dengan undang - undang.

6. Kepentingan Umum adalah kepentingan bangsa, Negara dan masyarakat yang harus diwujudkan oleh pemerintah dan digunakan sebesar-besarnya untuk kepentingan rakyat.

7. Hak Pengelolaan adalah hak menguasai dari Negara yang kewenangan pelaksanaannya sebagian dilimpahkan kepada pemegangnya.

8. Konsultasi Publik adalah proses komunikasi dialogis atau musyawarah antar pihak yang berkepentingan guna mencapai kesepahaman dan 
kesepakatan dalam perencanaan pengadaan tanah bagi pembangunan untuk kepentingan umum.

9. Pelepasan Hak adalah kegiatan pemutusan hubungan hukum dari pihak yang berhak kepada Negara melalui Lembaga Pertanahan.

10. Ganti Kerugian adalah penggantian yang layak dan adil kepada pihak yang berhak dalam proses pengadaan tanah.

11. Penilai Pertanahan, yang disebut penilai, adalah orang perserorangan yang melakukan penilaian secara independen dan profesional yang telah mendapat izin praktik penilaian dari Menteri Keuangan dan telah mendapat Lisensi dari Lembaga Pertanahan untuk menghitung nilai / harga objek pengadaan tanah.

12. Pemerintah Pusat, yang selanjutnya disebut Pemerintah, adalah Presiden Republik Indonesia yang memegang kekuasaan pemerintahan Negara Republik Indonesia sebagaimana dimaksud dalam Undang - Undang Dasar Negara Republik Indonesia tahun 1945.

13. Pemerintah Daerah adalah Gubernur, bupati atau Walikota dan perangkat daerah sebagai unsur penyelenggara pemerintahan daerah.

Lembaga Pertanahan adalah Badan Pertanahan Nasional Republik Indonesia, lembaga pemerintah yang menyelenggarakan urusan pemerintahan dibidang pertanahan. (Sutjahjo, K.D., 2005).

\section{Pendekatan Dalam Penilaian.}

\section{A. Pendekatan Pasar}

Pendekatan Pasar menghasilkan indikasi nilai dengan cara membandingkan aset yang dinilai dengan aset yang identik atau sebanding dan adanya informasi harga transaksi atau penawaran.

Dalam Pendekatan Pasar, langkah pertama adalah mempertimbangkan harga yang baru terjadi di pasar dari transaksi aset yang identik atau sebanding. Jika transaksi terakhir yang terjadi hanya sedikit, dapat mempertimbangkan dengan menggunakan harga yang ditawarkan (untuk dijual) atau yang terdaftar (listed) dari aset yang identik atau sebanding, relevansinya dengan informasi ini perlu diketahui secara jelas dan dengan seksama dianalisis.

\section{B. Pendekatan Biaya}

Pendekatan biaya adalah suautu metode untuk menetapkan nilai objek penilaian yang diperoleh dari penaksiran cost reproduction/replacement new, dikurngi denga perkiraan penghapusan karena penyusuta. Dengan mengunakan metode kalkulasi biaya nilai properti (tanah dan bangunan) diperoleh dengan menganggap tanah sebagai tanah kosong, nilai tanah dihitung dengan menggunakan metode perbandingan data pasar (market data approach). Sedangkan nilai bangunan dihitung dengan metode kalkulasi biaya. Nilai pasar bangunan dihitung dengan menghitung biaya reproduksi baru bangunan pada saat penilaian dikurangi penyusutan.

\section{Penilaian Tanah}

1. Penilaian untuk keperluan gantI rugi meliputi :

a. Ganti Rugi Fisik Tanah

Pendekatan utama dalam melakukan penilaian tanah adalah pendekatan pasar, dimana nilai tanah tidak seharusnya didasarkan pada harga yang diinginkan penjual, namun lebih kepada harga yang wajar yang akan dibayarkan oleh pembeli yang sangat berkeinginan membeli kepada penjual yang berkeinginan menjual tapi tidak sangat berkeinginan menjual pada tanggal penilaian. Dengan demikian penilai harus mempertimbangkan hal-hal yang mempengaruhi nilai tanah antara lain lokasi, bentuk, lingkungan, kedekatan dengan faktor positif serta negatif 
maupun karakteristik lingkungan, maupun penawaran yang ada terhadap tanah pada tanggal penilaian. (KPSPI,2015)

\section{b. Kerugian Non Fisik}

Kerugian Non Fisik Meliputi:

Penggantian terhadap kerugian pelepasan hak dari pemilik tanah yang akan diberikan premium serta diukur dalam bentuk uang berdasarkan ketentuan peraturan perundangundangan yang berlaku:

Penggantian ini dapat meliputi hal-hal yang berkaitan dengan:

1) Kehilangan pekerjaan atau kehilangan bisnis termasuk alih profesi (dengan mempertimbangkan UU No. 2 tahun 2012 pasal 33 huruf f berikut penjelasannya).

2) Kerugian emosional (solatium), merupakan kerugian tidak berwujud yang dikaitkan dengan pengambilalihan tanah yang digunakan sebagai tempat tinggal bagi pemilik (dengan memperhatikan UU No 2 Tahun 2012 pasal 1 Butir 10, pasal 2 berikut penjelasannya dan pasal 9 ayat 2).

3) Hal-hal yang belum diatur pada butir (1) dan (2) diatas seharusnya ditentukan berdasarkan kesepakatan para pihak yang terkait.

1. Biaya Transaksi, dapat meliputi biaya pindah dan pajak sesuai ketentuan peraturan perundang-undangan yang berlaku.

2. Kompensasi masa tunggu (bunga), yaitu sejumlah dana yang diperhitungkan sebagai pengganti adanya perbedaan waktu antara tanggal penilaian dengan perkiraan tanggal pembayaran ganti kerugian.

3. Kerugian sisa tanah, adalah turunnya nilai tanah akibat pengambilan sebagian bidang tanah. Dalam hal sisa tanah tidak lagi dapat difungsikan sesuai dengan peruntukannya, maka dapat diperhitungkan penggantian atas keseluruhan bidang tanahnya.

Kerusakan fisik lain, misalnya bagian bangunan yang terpotong akibat pengadaan tanah sehingga menimbulkan biaya perbaikan agar dapat berfungsi sebagaimana mestinya.

\section{METODE PENELITIAN}

Model studi kasus, studi kasus senantiasa dilaksanakan sebagai pilihan yang tepat menemukan jawaban dan pengetahuan dari suatu penelitian. Konteks penelitian ini telah diputuskan untuk mendalami komunikasi dalam Analisis penetapan nilai pengganti wajar dalam pengadaan tanah untuk kepentingan umum. Dengan demikian kecenderungannya dapat dikategorikan kepada model studi kasus dalam bentuk narasi yang akan memberikan hasil pemikiran yang komprehensif tentang deskripsi

Berdasarkan pada fokus permasatanah penelitian yang berupaya mengidentifikasi dan mendeskripsikan komunikasi krisis dalam organisasi maka data ataupun informasi yang dibutuhkan mencakup beberapa hal berikut:

1) Data yang berkaitan dengan Analisis penetapan nilai pengganti wajar dalam pengadaan tanah untuk kepentingan umum dikumpulkan melalui proses penelitian observasi di lapangan serta menghimpun data dan keterangan wawancara dari informan penelitian. Observasi langsung di lokasi penelitian akan menghimpun fenomena yang tampak secara rutin pada saat proses penetapan nilai ganti wajar. Data pada proses observasi ini diyakini akan sangat membantu proses analisis nantinya sehingga penulis memiliki deskripsi serta potret 
pengalaman yang jelas tentang hambatan penetapan nilai pengganti wajar dalam pengadaan untuk kepentingan umum, baik di dalam melakukan tugas dan pekerjaan dalam konteks formal maupun interaksi yang dilakukan dalam konteks di luar norma pekerjaan. Penentuan fenomena yang menjadi sumber data bagi penelitian ini tentunya dilaksanakan secara kondisional serta melihat kemungkinan relevansinya terhadap topik penelitian

2) Penelitian ini juga menetapkan penggunaan wawancara kepada masyarakat, Pemerintah Kota, Tim Appraisal serta BPN. Sumber data sebagaimana dilaksanakan berdasarkan teknik purposif yang selalu disesuaikan dengan konteks dan tujuan data yang ingin didalami. Proses pelaksanaan wawancara dilakukan dengan seksama dan tetap memperhatikan pedoman ataupun panduan interview (interview guidance) yang disusun sedemikian rupa sehingga proses wawancara yang dilaksanakan tetap terarah. Data yang berhasil dihimpun nantinya tergolong kepada data primer penelitian ini.

3) Penghimpunan data penelitian juga dilakukan melalui proses penelaahan terhadap dokumen-dokumen ataupun laporan yang berkaitan dengan fokus penelitian mengenai penetapan nilai pengganti wajar dalam pengadaan untuk kepentingan umum. Laporan yang ditelaah akan melalui proses mendapatkan persetujuan dari pihak yang berwenang di lokasi penelitian seperti pemerintah daerah, BPN dan pemilik tanah. Perlu disampaikan bahwasanya sangat dimungkinkan terdapat banyak laporan yang tersedia, akan tetapi laporan yang relevan bagi proses analisis data penelitian ini nantinya akan melalui proses pertimbangan awal dari ahli dan pihak yang berkewenangan tersebut. ( Creswell, W. 2015)

Lokasi penelitian yaitu dilakukan di Kecamatan Muara Dua Kota Lhokseumawe, Propinsi Aceh, Dan waktu penelitiannya dimulai November 2016 sampai Juli 2017.

\section{HASIL PENELITIAN}

\section{Gambaran umum Kota Lhokseumawe}

Kota Lhokseumawe adalah sebuah kota di provinsi Aceh. Kota ini berada persis di tengah-tengah jalur timur Sumatera. Berada di antara Banda Aceh dan Medan, sehingga kota ini merupakan jalur vital distribusi dan perdagangan di Aceh. Secara etimologi Lhokseumawe berasal dari kata Lhok dan Seumawe. Dalam bahasa Aceh, Lhok dapat berarti dalam, teluk, palung laut, dan Seumawe bermaksud air yang berputar-putar atau pusat mata air pada laut sepanjang lepas pantai Banda Sakti dan sekitarnya. Keberadaan kawasan ini tidak lepas dari kemunculan Kerajaan Samudera Pasai sekitar abad ke-13, kemudian kawasan ini menjadi bagian dari kedaulatan Kesultanan Aceh sejak tahun 1524. Sebelum abad ke-20, negeri ini telah diperintah oleh Uleebalang Kutablang. Tahun 1903 setelah perlawanan pejuang Aceh terhadap penjajah Belanda melemah, Aceh mulai dikuasai.

Lhokseumawe menjadi daerah taklukan dan mulai saat itu status Lhokseumawe menjadi Bestuur Van Lhokseumawe dengan Zelf Bestuurder adalah Teuku Abdul Lhokseumawe tunduk di bawah Aspiran Controeleur dan di Lhokseumawe berkedudukan juga Wedana serta Asisten Residen atau Bupati. Pada dasawarsa kedua abad ke-20 itu, di antara seluruh daratan Aceh, Kota Lhokseumawe sebagai salah satu pulau kecil dengan luas sekitar $11 \mathrm{~km}^{2}$ yang 
dipisahkan dengan sungai krueng cunda diisi bangunan-bangunan Pemerintah Umum, Militer, dan Perhubungan Kereta Api oleh Pemerintah Belanda.

Pulau kecil dengan desa-desa (Gampong) Kampung Keude Aceh, Kampung Jawa, Kampung Kutablang, Kampung Mon Geudong, Kampung Teumpok Teungoh, Kampung Hagu, Kampung Uteuen Bayi, dan Kampung Ujong Blang yang keseluruhannya baru berpenduduk 5.500 jiwa secara jamak di sebut Lhokseumawe.

Lhokseumawe ditetapkan statusnya menjadi kota berdasarkan UndangUndang Nomor 2 Tahun 2001, tanggal 21 Juni 2001 dengan batas-batas wilayah:

$$
\begin{array}{ll}
\text { Utara } & \text { : Selat Malaka } \\
\text { Selatan } & \text { : Kecamatan Kuta }
\end{array}
$$

Makmur Kabupaten Aceh Utara

$$
\text { Barat : Kecamatan }
$$

Dewantara Kabupaten Aceh Utara

Timur

Kecamatan

Syamtalira Bayu Kabupaten Aceh Utara

Penggunaan lahan terbesar di Kota Lhokseumawe adalah untuk permukiman seluas 10877 ha atau sekitar $60 \%$ dari luas yang ada. Kebutuhan lahan yang menonjol adalah untuk usaha kebun campuran 4.590 ha atau sekitar $25,35 \%$, di samping untuk kebutuhan persawahan seluas 3747 ha atau sekitar 21\%. Untuk kebutuhan perkebunan rakyat telah dimanfaatkan seluas 749 ha atau sekitar 4\% dan untuk lain-lainnya

\section{Analisa Pengadaan Tanah Untuk kepentingan Umum di Kota Lhokseumawe}

Salah satu cara pemenuhan kebutuhan negara atas tanah dapat dilakukan melalui lembaga pengadaan tanah. Hal ini berarti bahwa negara mengambil hak privat (atas tanah) dari pemiliknya dengan cara pelepasan hak secara sukarela dari pemiliknya dengan memberikan kompensasi berupa ganti kerugian berdasar peraturan perundangan yang berlaku. Dalam peraturan yang melandasi pengambil alihan tanah oleh negara, banyak istilah yang digunakan yakni fungsi sosial , kepentingan umum dan kepentingan pembangunan.

Istilah tersebut kadang dipakai untuk melegalkan pengambil alihan tanah oleh pemerintah untuk memenuhi keperluan tanah guna kegiatan investasi . Konsep kepentingan umum tidak pernah dirumuskan dengan memadai dalam hukum positif, hal ini sebagai konsekwensi dari konsep kepentingan umum yang tidak dapat didefinisikan pengertiannya.Kepentingan umum hanya konsep yang dapat ditetapkan kriterianya saja, dan tidak dapat dirumuskan pengertiannya. Kepentingan umum adalah konsep hukum yang kabur, hanya untuk alasan praktis konsep kepentingan umum diterapkan. (Budhayati , 2012).

Kota Lhokseumawe memiliki luas wilayah $181,10 \quad \mathrm{~km}^{2}$, yang secara Administratif Kota Lhokseumawe terbagi kedalam 4 Kecamatan dan 68 Gampong. Kecamatan-kecamatan di Kabupaten Lhokseumawe :

1. Kecamatan Banda Sakti

2. Kecamatan Muara Dua

3. Kecamatan Blang Mangat

4. Kecamatan Muara Satu

a. Harga Penawaran

Data pasar pembanding disekitar properti yang kita gunakan dapat berupa data transaksi dan atau data penawaran. Tidak semua data yang kita dapatkan di lapangan dapat kita jadikan pembanding, dari data-data yang terpilih dan terverifikasi kita gunakan dalam analisa/adjustifikasi nilai tanah. Data Pembanding yang kami gunakan dalam penilaian ini adalah sebagai berikut:
1. Sumber Data
: Nama dan
Alamat Ada pada working paper
Luas Tanah $\quad: \pm 2.000 \mathrm{~m}^{2}$ 
Jenis Properti

Tanah kosong

Surat Kepemilikan : sporadik

Harga transaksi $\quad:$ Rp.

400.000.000,-

2. Sumber Data : Nama dan

Alamat Ada pada working paper

Luas Tanah $\quad: \pm 1.500 \mathrm{~m}^{2}$

Jenis Properti

Tanah kosong

Surat Kepemilikan : Sporadik

Harga Transaksi : Rp.

315.000.000,-

3. Sumber Data : Nama dan

Alamat Ada pada working paper

Luas Tanah

$: \pm 1.800 \mathrm{~m}^{2}$

Jenis Properti

Tanah kosong

Surat Kepemilikan : Sporadik

Harga Transaksi : Rp.

360.000.000,-

4. Sumber Data : Nama dan

Alamat Ada pada working paper

Luas Tanah $\quad: \pm 450 \mathrm{~m}^{2}$

Jenis Properti

Tanah kosong

Surat Kepemilikan : SHM

Harga Transaksi :

Rp.180.000.000,-

5. Sumber Data : Nama dan

Alamat Ada pada working paper

Luas Tanah $\quad: \pm 250 \mathrm{~m}^{2}$

Jenis Properti

Tanah kosong

Surat Kepemilikan : SHM

Harga Transaksi: Rp.

125.000.000,-

6. Sumber Data : Nama dan

Alamat Ada pada working paper

Luas Tanah $\quad: \pm 840 \mathrm{~m}^{2}$

Jenis Properti

Tanah kosong

Surat Kepemilikan : SHM
Harga Transaksi: $\quad$ Rp. 340.000 .000

7. Sumber Data : Nama dan

Alamat Ada pada working paper

Luas Tanah $\quad: \pm 1.206 \mathrm{~m}^{2}$

Jenis Properti

Tanah kosong

Surat Kepemilikan : SHM

Harga Penawaran

Rp. 783.900.000,

8. Sumber Data : Nama dan

Alamat Ada pada working paper

Luas Tanah $\quad: \pm 450 \mathrm{~m}^{2}$

Jenis Properti

Tanah kosong

Surat Kepemilikan : SHM

Harga Penawaran

Rp. 306.000.000,-

9. Sumber Data : Nama dan

Alamat Ada pada working paper

Luas Tanah $\quad: \pm 1.120 \mathrm{~m}^{2}$

Jenis Properti

Tanah kosong

Surat Kepemilikan : sporadik

Rp. 672.000.000,Harga Transaksi :

Pelaksanaan pemberian ganti rugi bagi pemegang hak atas tanah, seringkali aspek keadilan dikesampingkan dan yang diutamakan adalah kepastian dan kemanfaatan. Sebagai contoh dalam pelaksanaan pelebaran jalan raya di Kota Praya terdapat pemilik hak atas tanah yang terkena pelebaran jalan dimana ganti rugi yang diberikan tidak sesuai dengan yang seharusnya.

Pasal 65 ayat (1) Peraturan Presiden Nomor 71 Tahun 2012 menentetukan bahwa: Penilai bertugas melakukan penilaian besarnya Ganti Kerugian bidang per bidang tanah, meliputi:
a. tanah;
b. ruang atas tanah dan bawah tanah;
c. bangunan;
d. tanaman; 
e. benda yang berkaitan dengan tanah; dan/atau

f. kerugian lain yang dapat dinilai.

Maksudnya banhwa tim Penilai melakukan penilaian terkait berapa besar ganti kerugian yang harus ditanggung dalam Pengadaan Tanah tersebut. Besarnya ganti kerugian tidak hanya terhadap tanah, tetapi terhadap kerugian lain yang timbul akibat Pengadaan Tanah. Nilai Ganti Kerugian yang dinilai oleh Penilai diumumkan pada saat Penetapan Lokasi pembangunan. Pasal 66 ayat (1) Peraturan Presiden Nomor 71 Tahun 2012 menentukan bahwa: Nilai Ganti kerugian yang dinilai oleh Penilai sebagaimana dimaksud dalam Pasal 65 merupakan nilai pada saat pengumuman Penetapan Lokasi pembangunan untuk Kepentingan Umum Kereta Api Lhoksemawe.

\section{PEMBAHASAN}

Berdasarkan uraian bab tedahulu maka dapat disimpulkan :

1. Penetapan nilai pengganti wajar Dalam Pembebasan Tanah Untuk Kepentingan Umum Di Kota Lhokseumawe menyangkut penguasaan yuridis dilandasi hak, yang dilindungi oleh hukum dan umumnya memberi kewenangan kepada pemegang hak untuk menguasai secara fisik tanah yang dihaki. Tetapi ada juga penguasaan yuridis yang meskipun memberikan kewenangan untuk menguasai tanah yang dihaki secara fisik, pada kenyataannya penguasaan fisiknya dilakukan oleh pihak lain.

2. Hamabatan-hambatan dlam pelaksanaan pemerian ganti kerugian dalam pengadaan tanah untuk pembangunan jalur rel kereta api di Kota Lhokseumawe adalah ahambatan yang berasal dari masyarakat pemegang hak atas tanah, bangunan dan tanaman serta benda-benda yang berkaitan dengan tanah adalah kurangnya kesadaran masyarakat untuk berperan serta dalam pembangunan dan kurang pemahaman terhadap arti kepentingan umum, fungsi sosial hak atas tanah, akibat kurangnya pemahaman mengenai rencana dan tujuan pembangunan proyek tersebut yang sebelumnya telah dilakukan sosialisasi oleh paitia pengadaan tanah untuk pembangunan rel kereta api di Kota Lhokseumawe.

3. Adanya perbedaan pendapat serta keinginan dalam menentukan bentuk dan besarnya ganti kerugian antara pemegang hak yang satu dengan pemegang hak yang lainnya terjadi karena pemilik tanah cenderung mementingkan kepentingan individu atau nilai ekonomis tanah untuk pembanunan rek kereta api di Kota :Lkhoseumawe.

4. Dalam proses pengadaan tanah ada beberapa tahapan yang harus dilakukan, yaitu perencanaan,persiapan, pelaksanaan, dan penyerahan hasil.

5. Besarnya ganti kerugian terhadap lokasi pembangunan untuk kepentingan umum, nilainya berdasarkan nilai pengganti wajar yang dikeluarkan oleh Kantor Jasa Penilai Publik. Dalam proses penetapan nilai pengganti wajar yang ditetapkan oleh tim independen ( Appraisal) telah sesuai dengan Standar Penilaian Indonesia (SPI 2015,306) serta UU No 2 tahun 2012 Tentang Pengadaan Tanah Untuk Kepentingan Umum, Pasal 33 
Penilaian besarnya ganti kerugian oleh penilai sebagaimana dimaksud dalam pasal 32 ayat (1) dilakukan bidang perbidang tanah,meliputi :
a. Tanah
b. Ruang atas tanah dan bawah tanah
c. Bangunan
d. Tanaman
e. Benda yang berkaitan dengan tanah, dan/atau
f. Kerugian lain yang dapat dinilai.

6. Masih ada saja masyarakat yang merasa kurang puas, terutama mengenai nilai pasar tanah, hal ini dikarenakan beranggakapan bahawa tanah mereka sama dengan tanah yang lain kenapa nilai pasar tanahnya berbeda. .

7. Penentuan nilai tanah didasarkan pada nilai pengganti yang ditetapkan oleh tim appraisal yang hasil akhirnya dapat dimanfaatkan untuk memperoleh tanah dan bangunan yang semula dimiliki oleh yang bersangkutan atau mampu menghasilkan spendapatan yang sama sebelum tanah tersebut diambilalih. Oleh karena belum semua warga menyepakati nilai ganti rugi, maka masalah pemberian ganti kerugian dalam pengadaan tanah mengalami hambatan.

Berdasarkan uraian kesimpulan diatas maka dengan ini peneliti memberikan saran sebagai berikut :

1. Pemerintah kota perlu malakukan sosialisasi secara maksimal dan intensif tentang Undang-undangNo 2 Tahun 2012 untuk pelakasana maupun masyarakat, sehingga terdapat suatu persamaan persepsi mengenai pengertian, makna, tujuan dan prosedur pengadaan tanah bagi pembangunan untuk kepentingan umum.

2. Pemerintah sebaiknya melakukan sosialisasi secara jelas dan memberikan pemahaman kepada masyarakata tentang nilai yang dikeluarkan oleh tim appraisal.

3. Diharapkan untuk tim penilai agar lebih memperhatikan nilai pasar tanah masyarakat, supaya tidak ada lagi masyarakat yang protes atau tidak setuju dengan hasil penilaian dari tim appraisal.

4. Pemerintah sebaaiknya memudahkan warga dalam proses pelepasan tanah untuk kepentingan umum dalam hal ini berkaitan dengan administrasi.

\section{DAFTAR PUSTAKA}

Adi, W., 2013, "Analisis Perkiraan Nilai Ganti Kerugian Pada Pengadaan Tanah Bagi Pembangunan Untuk Kepentingan Umum", Tesis tidak diterbitkan, Magister Ekonomika Pembangunan, Universitas Gadjah Mada, Yogyakarta.

Adiguna, Chendra Mokoagow, 2015, Penentuan Tolok Ukur Tanah Untuk Kepentingan Umum Berdasar Pada Uu No. 5 Tahun 19601, Lex Administratum, Vol. III/No.1/Jan-Mar/2015, hal.95-106.

Amgasussari Anugrahni Sangalang,2012, Kajian Terhadap Ganti Rugi Atas Tanah Dalam Pengadaan Tanah Bagi Pembangunan Untuk Kepentingan Umum Guna Mewujudkan Kepastian Hukum, Perlindungan Hukum, Dan Keadilan Berdasarkan Peraturan Presiden Nomor 36 Tahun 2005 Dan Peraturan Presiden Nomor 65 Tahun 2006, Program Studi Magister Ilmu Hukum Program Pascasarjana Universitas Atma Jaya Yogyakarta 2012

Baihaqi, 2014, Landasan Yuridis Terhadap Aturan Hukum Tentang Pengadaan Tanah Untuk Kepentingan Umum, Jurnal Ilmiah Peuraden, Media kajian ilmiah sosial, politik, hukum, agama dan budaya, Vol.ii.No.02, May, 2014, hal.132-134. 
B Limbong, 2011. Pengadaan Tanah Untuk Pembangunan: Regulasi- KompensasiPenegakan Hukum, Pustaka Margaretha, Jakarta.

Candra, Wahyu Alam, 2010, "Pengadaan Tanah Untuk Kepentingan Umum Kurang Dari Satu Hektar Dan Penetapan Ganti Kerugiannya (Studi Kasus Pelebaran Jalan Gatot Subroto Di Kota Tangerang)”, Semarang : Universitas Diponegoro.

Chang, Y.C., 2012. "Economic Value or Fair Market Value: What Form of Takings Compensation Is Efficient?", Supreme Court Economic Review, Volume 20: 3588, University of Chicago.

Creswell, John, W. 2015. Penelitian Kualitatif \& Desain Riset.Yogyakarta : Pustaka Belajar Djunaedi, Achmad, Keragaman Pilihan Corak Perencanaan (PlanningStyles)untuk Mendukung Kebijakan Otonomi Daerah, Jogjakarta : Program Magister Perencanaan Kota Dan Daerah Universitas Gadjah Mada.

Emmy, Marni Mustafa,2012, Penawaran Pembayaran Tunai Dan Konsignasi D Pengadilan Untuk Pengadaan Tanah Bagi Pembangunan Untuk Kepentingan Umum, Pengadilan Tinggi Jawa Barat.

Harjanti,Budi \& Hidayati Wahyu, 2014 Konsep Dasar Penilaian Properti,Edisi Kedua, Yogyakarta

Hery Zarkasih, 2015, Pelaksanaan Prinsip Keadilan Dalam Pemberian Ganti | Rugi Pengadaan Tanah Untuk Kepentingan Umum (Studi Kasus Pelebaran Jalan Raya Di Kota Praya Kabupaten Lombok Tengah), Magister Ilmu Hukum Universitas Mataram, Kajian Hukum Dan Keadilan.

Joseph Maxwell, A. 2013. Qualitative Research Design, An interactive Approach (3rd Ed.). Sage Publications, Inc.

Mulyanti, Rini , 2013, Analisis Pengadaan tanah Untuk kepentingan Umum (Studi Kasus Pembangunan Jalan Tol Jorr West 2), Depok : Universitas Indonesia

Mohammad Paurindra Ekasetya, 2015, Pelaksanaan Pengadaan Tanah Bagi
Pembangunan Untuk Kepentingan Umum (Studi Analisis Pada Pembangunan Jalan Tol Trans Jawa Di Kabupaten Brebes), Semarang : Fakultas Hukum Universitas Negeri Semarang.

Prawoto, A., 2005. Teori dan Praktek Penilaian Properti, Edisi Pertama. Fakultas Ekonomi UGM, Yogyakarta.

Sutjahjo, K.D., 2005, "Model kompensasi pembebasan tanah untuk pembangunan jalan perkotaan: studi kasus jalan Dewi Sartika - jalan Sawangan Depok", Tesis, Pengembangan Perkotaan, Pascasarjana Universitas Indonesia, Depok.

Samli, Asbi, 2012, Analisis Pengembangan Kota Berdasarkan Kondisi Fisik Wilayah Kota Masohi Ibukota Kabupaten Maluku Tengah, Jurnal Plano Madani Vol. I Nomor 1/2012, hal 74-75.

Santoso, Urip, 2013, kewenangan Pemerintah Daerah Dalam Penguasaan Ata Tanah, Surabaya : Universitas Airlangga, Jurnal Dinamika Hukum Vol. 13 No. 1 Januari 2013.

Tri, Christiana Budhayati , 2012, Kriteria Kepentingan Umum Dalam Peraturan Pengadaan Tanah Untuk Kepentingan Pembangunan Di Indonesia, Jurnal Ilmu Hukum REFLEKSI HUKUM Edisi April 2012.

Vitanen, K. dan Kakulu, I., 2009. "Global Concerns in Compulsory Purchase and Compensation Processes", International Federation of Surveyors, Article of the Month - February 2009.

Wunas, Shirly dan Venny Veronica Natalia, Pembangunan Infrastruktur Transportasi di Kota Makassar, Jurnal Transportasi Vol. 15 No. 3 Desember 2015: 169-178.

KPSPI, 2015. Petunjuk Teknis Penilaian Terhadap Pengadaan Tanah Bagi Pembangunan Untuk Kepentingan Umum (SPI 306), Edisi 1 Januari 2015, MAPPI, Jakarta.

Kode Etik penilai Indonesia dan standar Penilaian Indonesia edisi VI-2015 SPI 306-1.2.Pasal 1 angka 3 Perpres No. 36 Tahun 2005. 
http://www.antaranews.com/berita/528362/jalurka-sepanjang-189-km-akan membelahlhokseumawe diunduh pada 10 desember 2017, pukul 13.45 wib.

http://www.bphn.go.id/data/documents/lap._akihir mbak yul.pdf diunduh pada 6 juni 2017, pukul 15.45 wib.

KPSPI, 2015. Petunjuk Teknis Penilaian Terhadap Pengadaan Tanah Bagi Pembangunan Untuk Kepentingan Umum (SPI 306), Edisi 1 Januari 2015, MAPPI, Jakarta.

http://repository.ipb.ac.id/bitstream/handle/12345
6789/2708/BAB\%20II\%20TINJAUAN\%20PUST AKA.pdf;jsessionid=F9C87D7FD06DDE327EEC C3339AB7449C? sequence $=7$ diunduh pada tanggal 6 juni 2017, pukul 12.30 wib.

http://ddc-kota-

lhokseumawe.blogspot.co.id/2011/12/gambaranumum-kota-lhokseumawe.html

http://webcache.googleusercontent.com/search?q= cache:hvdDUxmRtlkJ:adeheryana.weblog.esaung gul.ac.id/wp-

content/uploads/sites/5665/2017/05/Ade

Heryana Kerangka-Teori-Kerangka-KonsepHipotesis-dan-

Variabel.pdf $+\& \mathrm{~cd}=6 \& \mathrm{hl}=\mathrm{id} \& \mathrm{ct}=\mathrm{clnk} \& \mathrm{gl}=\mathrm{id}$ 